\title{
$\beta$-Glycosidase of Potato
}

\author{
By P. BARUAH* AND T. SWAIN \\ Low Temperature Station for Research in Biochemistry and Biophysics, University of Cambridge, \\ and Department of Scientific and Industrial Research
}

(Received 3 December 1956)

It has been shown by Bate-Smith (1949) and others (Nordström \& Swain, 1953; Ice \& Wender, 1953) that most of the low-molecular-weight phenolic compounds in plant tissues occur as glycosides. An examination of the phenolic constituents of potato tuber (Baruah \& Swain, unpublished) has indicated that, in this tissue also, only small amounts of aglycones are present.

Roberts \& Wood (1951) demonstrated that tealeaf phenolase had no action on certain flavonol glycosides, whereas the corresponding aglycones were readily oxidized. Investigation of the specificity of potato phenolase towards a number of naturally occurring phenolic compounds (Baruah \& Swain, in preparation) has shown similar results. Since it is known that the majority of phenolic glycosides have a $\beta$-sugar link, it was considered likely that the concentration of aglycone, and hence possibly the activity of the phenolase system, would be determined by the activity of $\beta$-glycosidase present in the tissue.

The present investigation was limited to demonstrating the occurrence of $\beta$-glucosidase in potato tissue. For the preliminary studies a new method for measuring $\beta$-glucosidase activity with salicin as substrate was developed; in this the amount of saligenin formed was determined colorimetrically by use of 4-aminoantipyrine (Martin, 1949).

\section{EXPERIMENTAL}

Materials. Salicin was a commercial preparation [Baird and Tatlock (London) Ltd.] and was recrystallized from water before use. Emulsin was prepared from sweet almonds (Helferich, Winkler, Goetz, Peters \& Gunther, 1932).

\section{Measurement of $\beta$-glucosidase activity}

Reagents. A. 4-Aminoantipyrine ( 0.1 g.) in $50 \%(\mathrm{v} / \mathrm{v})$ aq. ethanol (10 ml.) and $2 \mathrm{~N}$-ammonium hydroxide $(25 \mathrm{ml}$.) were mixed and diluted to $250 \mathrm{ml}$. with water.

$B$. Potassium ferricyanide solution $(0 \cdot 2 \%)$.

Calibration curve. This was prepared by mixing varying proportions of salicin, saligenin and glucose in $10 \mathrm{ml}$. of water to give a final concentration of $0 \cdot 1 \mathrm{~mm}$ in respect to the total amount of glycoside plus aglycone. To this solution was added $5 \mathrm{ml}$. of reagent $A$ followed by $5 \mathrm{ml}$. of reagent $B$.

* Wheldale Onslow Research Fellow, Newnham College, Cambridge.
The solutions were mixed in $2.5 \mathrm{~cm}$. diam. standardized tubes and, after $5 \mathrm{~min}$., the optical density was measured at $515 \mathrm{~m} \mu$ with a Unicam SP. 300 spectrophotometer.

Tests with emulsin. Salicin (0.1 g.) in $0.1 \mathrm{M}$-disodium hydrogen citrate buffer of the required $\mathrm{pH}(5 \mathrm{ml}$.) and emulsin $(0.1 \mathrm{~g}$.) in buffer $(10 \mathrm{ml}$.) were well mixed and incubated at $35^{\circ}$. Samples $(0.5 \mathrm{ml}$.) were taken from time to time and added to ethanol $(9.5 \mathrm{ml}$.), and the protein was removed by centrifuging. A portion $(1 \mathrm{ml}$.) of the supernatant was diluted with water $(9 \mathrm{ml}$.) and the concentration of saligenin determined as described above. A control solution was run without enzyme for each measurement. The determination of saligenin was not affected by the presence of emulsin; the alcohol-precipitation step is therefore not essential.

\section{Preparation of potato extract for demonstrating $\beta$-glucosidase activity}

Freeze-dried potato powder (prepared from King Edward potatoes) was washed three times with ice-cold acetone ( $2 \mathrm{ml} . / \mathrm{g}$.$) and then with ice-cold 70 \%(\mathrm{v} / \mathrm{v})$ ethanol ( $2 \mathrm{ml} . / \mathrm{g}$.) until the filtrate showed no trace of fluorescent material when viewed under an ultraviolet lamp and gave no reaction with a solution of ferric chloride in ethanol. The residue was dried in vacuo and extracted with water $(0.5 \mathrm{ml}$./ g.). For assay, $5 \mathrm{ml}$. of this solution was mixed with $0 \cdot 1 \mathrm{M}$ citrate buffer $(5 \mathrm{ml}$.$) and, after equilibration at 35^{\circ}$, salicin $(0 \cdot 1$ g.) in buffer $(5 \mathrm{ml}$.) was added.

\section{RESULTS}

The standard curve for saligenin as determined by the 4-aminoantipyrine method is shown in Fig. 1. It will be seen that as little as $1 \mu \mathrm{g}$. of saligenin $/ \mathrm{ml}$. can be detected in the $10 \mathrm{ml}$. of solution taken for the determination. The method was applied to the determination of the rate of hydrolysis of salicin by emulsin (Fig. 2) and to the determination of the pH optimum of this enzyme (Fig. 3). The demonstration of the presence of a $\beta$-glucosidase in the potato extract and determination of its $\mathrm{pH}$ optimum is also shown in Figs. 2 and 3.

\section{DISCUSSION}

The various methods for determining $\beta$-glucosidase activity have been described by Veibel (1941). It has been usual in the past to employ a naturally occurring $\beta$-glucoside such as salicin, arbutin or cellobiose and to determine the degree of hydrolysis polarimetrically or reductometrically. Although

\footnotetext{
Bioch. 1957, 66
} 


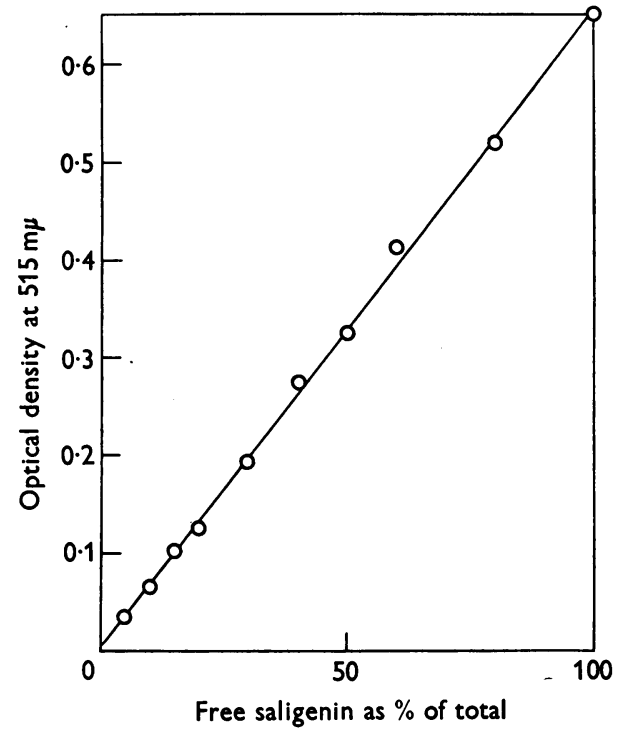

Fig. 1. Calibration curve for saligenin. (For details see Experimental section.)

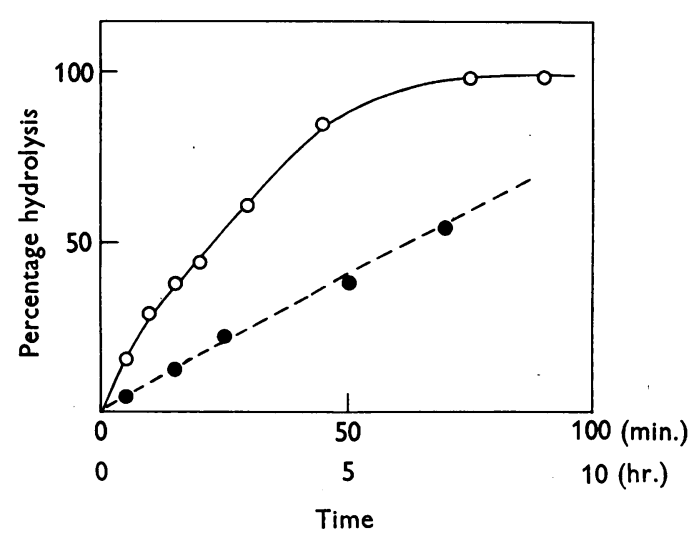

Fig. 2. Hydrolysis of salicin by emulsin and potato $\beta$ glycosidase at pH 5.0. (For details see Experimental section.) $O$, Emulsin (time scale in min.); 0 , potato extract (time scale in hours).

such methods are still in use (Veibel \& Yang, 1952) they are tedious and their lack of specificity is a serious disadvantage in routine assays of $\beta$ glucosidase, especially in crude extracts (cf. Kerr, Graham \& Levvy, 1948). In recent years, following on the work of Aizawa (1939), many workers have employed as substrates synthetic $\beta$-glucosides, the aglycone of which can be readily determined colorimetrically (Conchie, 1954; Cohen, Rutenburg, Tsou, Woodbury \& Seligman, 1952). Jermyn (1952) pointed out, however, an objection to the use of $p$-nitrophenyl- $\beta$-D-glucoside as a substrate. He found that although the $\beta$-glucosidase from

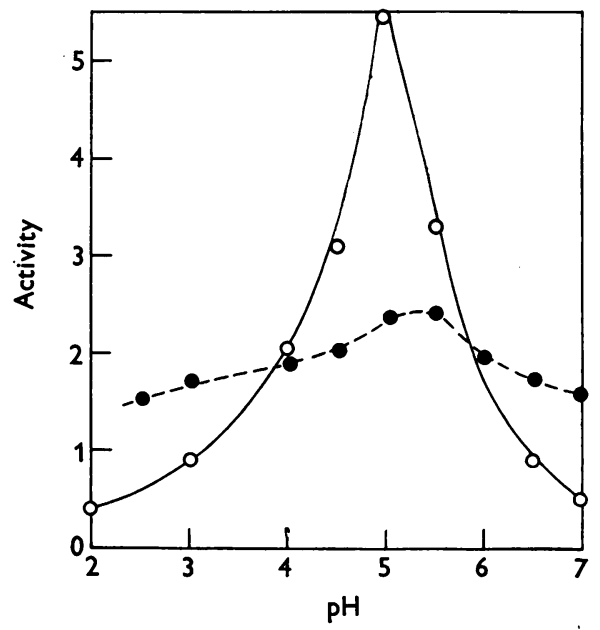

Fig. 3. Effect of $\mathrm{pH}$ on activity of emulsin and potato $\beta$-glucosidase. (For details see Experimental section.) O, Emulsin; , potato $\beta$-glycosidase.

Aspergillus oryzae could be separated by paper electrophoresis into several components, none of which was specific towards salicin, aesculin or sodium carboxymethylcellulose, only one of these components would hydrolyse the $p$-nitrophenol derivative, and furthermore it appeared to be part of a separate system unrelated to the rest. It seemed useful therefore to develop a method for estimating $\beta$-glucosidase activity which is free from such defects and which is capable of determining initial rates of activity before the aglycone concentration is high enough to interfere seriously in the measurement (cf. Veibel \& Lillelund, 1938). From the results obtained, it appears that the method described meets these requirements and, unlike previous colorimetric methods, it uses a generally accepted substrate which is available commercially. Furthermore, its sensitivity is sufficient to detect changes of the order of $0.05 \mu$ mole of substrate, so that very small amounts of enzyme can be used (cf. Hofstee, 1955). The results obtained for the $\mathrm{pH}$ optimum for emulsin agree with those of other workers (Veibel, 1941). The potato extract shows, as had been expected, the presence of $\beta$-glucosidase activity (Latzko, 1954). A noteworthy feature of this system is its low sensitivity to $\mathrm{pH}$ changes.

\section{SUMMARY}

1. A new method for determining $\beta$-glycosidase activity has been developed with salicin as the substrate.

2. By this method the presence of $\beta$-glucosidase activity in potato has been demonstrated.

The work described in this paper was carried out as part of the programme of the Food Investigation Organization of the Department of Scientific and Industrial Research. 


\section{REFERENCES}

Aizawa, K. (1939). J. Biochem., Tokyo, 30, 89.

Bate-Smith, E. C. (1949). Symp. biochem. Soc. no. 3, p. 62. Cohen, R. B., Rutenburg, S. M., Tsou, K. C., Woodbury, M. A. \& Seligman, A. M. (1952). J. biol. Chem. 195, 607. Conchie, J. (1954). Biochem. J. 58, 552.

Helferich, B., Winkler, S., Goetz, R., Peters, O. \& Gunther, E. (1932). Hoppe-Seyl. Z. 208, 91.

Hofstee, B. H. J. (1955). Arch. Biochem. Biophys. 59, 398. Ice, C. H. \& Wender, S. M. (1943). J. Amer. chem. Soc. 75, 50.
Jermyn, M. A. (1952). Aust. J. sci. Res. B, 5, 433.

Kerr, L. M. H., Graham, A. F. \& Levvy, G. A. (1948). Biochem. J. 42, 191.

Latzko, E. (1954). Z. PflErnähr. Düng. 66, 148.

Martin, R. W. (1949). Analyt. Chem. 21, 1419.

Nordström, C. G. \& Swain, T. (1953). J. chem. Soc. p. 2764

Roberts, E. A. H. \& Wood, D. J. (1951). Nature, Lond., 167, 608.

Veibel, S. (1941). In Die Methoden der Fermentforschung. Ed. by Bamann, E. \& Myrbäck, K. Leipzig: Thieme.

Veibel, S. \& Lillelund, M. (1938). Enzymologia, 5, 129.

Veibel, S. \& Yang, S. L. (1952). Acta chem. scand. 6, 1366.

\title{
The Metabolism of 8-Azapurines
}

\author{
By J. D. SMITH AND R. E. F. MATTHEWS* \\ Agricultural Research Council Virus Research Unit, Molteno Institute, University of Cambridge
}

\section{(Received 8 October 1956)}

8-Azaguanine inhibits growth or development of many organisms and viruses. These include several transplantable tumours (e.g. Kidder, Dewey, Parks \& Woodside, 1949, 1951; Sugiura, Hitchings, Cavalieri \& Stock, 1950; Law, 1950; Finkelstein \& Thomas, 1951), the chick embryo (Youngner, Ward \& Salk, 1950), Tetrahymena (Kidder \& Dewey, 1949), bacteria (Roblin, Lampen, English, Cole \& Vaughan, 1945; Hitchings, Elion, Falco \& VanderWerff, 1947; Hitchings, Elion, Falco, Russell \& VanderWerff, 1950; Lasnitzki, Matthews \& Smith, 1954) and some plant viruses (Matthews, 1953, $1954,1955)$. In many of these systems it has been shown that 8-azaguanine is incorporated into ribonucleic acids (RNA) replacing a proportion of the guanine residues. The amounts of 8-azaguanine

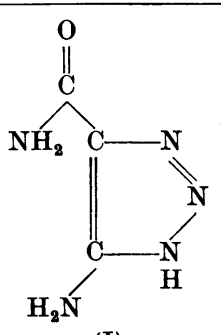

(I)

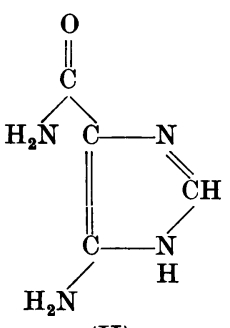

(II) found in RNA are usually low, varying between 1 and $5 \%$ of the guanine content. We have, however, found that Bacillus cereus incorporates 8-azaguanine into its RNA with replacement of up to $40 \%$ of the guanine. With this organism we have studied the distribution of 8-azaguanine in the bacterial RNA.

We have also investigated the effects of similar analogues of purines and their precursors on bacteria

* Present address: Plant Diseases Division, Department of Scientific and Industrial Research, Auckland, New Zealand. and tobacco mosaic virus. These include 8-azaadenine and certain substituted triazoles. 5(4)Amino- $1 H$-1:2:3-triazole-4(5)-carboxyamide (I) is an analogue of 5(4)-amino-1 $H$-1:2:3-imidazole-4(5)carboxyamide (II), the purine precursor described by Shive, Ackermann, Gordon, Getzendaner \& Eakin (1947). Some preliminary results of this work have been reported (Matthews \& Smith, 1954, 1956).

\section{MATERIALS AND METHODS}

8-Azapurines and substituted triazoles. These were gifts from the American Cyanamid Co. 8-Aza-adenosine was a gift from Dr J. Davoll. Guanine and hypoxanthine were commercial products. The purity of all these substances was checked by paper chromatography in several solvents.

\section{Growth of bacteria and viruses}

Escherichia coli. E. coli strain B/r (Witkin, 1951) was grown in synthetic media. Medium $A$ comprised: $\mathrm{KH}_{2} \mathrm{PO}_{4}$, $13 \cdot 6$ g.; $\left(\mathrm{NH}_{4}\right)_{2} \mathrm{SO}_{4}, 3 \cdot 3 \mathrm{~g}$; $\mathrm{MgSO}_{4}, 7 \mathrm{H}_{2} \mathrm{O}, 0 \cdot 4 \mathrm{~g}$.; $\mathrm{CaCl}_{2}$, $10 \mathrm{mg}$.; $\mathrm{FeSO}_{4}, 7 \mathrm{H}_{2} \mathrm{O}, 0.5 \mathrm{mg}$.; glucose, $10 \mathrm{~g}$; $\mathrm{NaOH}$ to $\mathrm{pH} 7$ and water to $1 \mathrm{l}$. Medium $\mathrm{H}$ comprised $\mathrm{Na}_{2} \mathrm{HPO}_{4}, 6 \mathrm{~g}$.; $\mathrm{KH}_{2} \mathrm{PO}_{4}, 3 \mathrm{~g}$.; $\mathrm{MgSO}_{4}, 7 \mathrm{H}_{2} \mathrm{O}, 0 \cdot 2 \mathrm{~g}$; $\mathrm{NaCl}, 0 \cdot 5 \mathrm{~g}$.; $\mathrm{NH}_{4} \mathrm{Cl}, 1 \mathrm{~g}$.; glucose, 0.4 g.; water to 1 l. (Herriott \& Barlow, 1952). In making up these media the glucose was autoclaved separately. The growth rates of the bacteria and their behaviour towards the purine analogues were identical in both media.

A purine-requiring strain of $E$. coli (55) was obtained from Dr E. Wollman of the Institut Pasteur, Paris. This was grown in $H$ medium supplemented with adenine or guanine. Bacillus cereus strain 569 H (Kogut, Pollock \& Tridgell, 1956) was grown on a medium comprising: vitamin-free casein hydrolysate, $10 \mathrm{~g}$.; $\mathrm{KH}_{2} \mathrm{PO}_{4}, 3.5 \mathrm{~g}$.; $\mathrm{MgSO}_{4}, 7 \mathrm{H}_{2} \mathrm{O}$, $0.51 \mathrm{~g}$.; $\left(\mathrm{NH}_{4}\right)_{2} \mathrm{Fe}\left(\mathrm{SO}_{4}\right)_{2}, 6 \mathrm{H}_{2} \mathrm{O}, 4.8 \mathrm{mg}$.; $\mathrm{NaOH}$ to $\mathrm{pH} 7$ and water to 11 .

Bacteria were grown at $37^{\circ}$, either in 61 . bottles with vigorous aeration from an air compressor or in flasks on a rotary shaker. Samples for the isolation of nucleic acid were chilled to $4^{\circ}$, and the bacteria were sedimented in the centrifuge and washed once in $0.14 \mathrm{M}-\mathrm{NaCl}$ or $0.05 \mathrm{M}$-sodium 